\title{
Future-property as the Property of the Future
}

\author{
Propertyological Aspect*
}

\author{
Andrey Orekhov \\ Department of Social Philosophy \\ Peoples' Friendship University of Russia \\ 6 Miklukho-Maklaya Street \\ Moscow, Russia \\ E-mail: orekhovandrey@yandex.ru
}

\author{
Aleksey Neugodnikov \\ Department of Social Philosophy \\ Peoples' Friendship University of Russia \\ 6 Miklukho-Maklaya Street \\ Moscow, Russia \\ E-mail: neugodnikovap2016@yandex.ru
}

\begin{abstract}
Current research in the social sciences requires the creation of the new transdisciplinary fields. A place among them could take propertyology - interdisciplinary science on the property. Future-property as the property of the future us experiencing the following trends in its transformation: the increasing significance of the new types of property, in particular, the intellectual property and the property on a human body; the increase of the intellectual component of the future-property as a whole; the rising complexity of the structure of the property, its acquisition of the network character.
\end{abstract}

Keywords-propertyology; future-property; property; future; network society; economic development

\section{INTRODUCTION}

"Propertyology" is a new interdisciplinary branch of knowledge, developing the interdisciplinary theory of property. The term emerged in A.M. Orekhov and M.V. Skachko's article "The Philosophy of Property as a Prerequisite to Propertyology" [1]. Both authors, exploring the current state of sciences studying property, come to conclusion about the necessity of creating a global interdisciplinary science of property - propertyology.

Propertyology is a global science on the property, revealing intra-disciplinary and transdisciplinary discourses of the said institution, summarizing its social practices, and constructing against this background a universal social theory of property.

What tasks must propertyology perform in the field of socio-humanitarian knowledge? In our opinion, there are only six tasks, or, better to say, functions:

Ideological function. This function consists in organizing and ordering the worldview of an individual regarding the problems of property; chaotic, anarchic, amorphous views of certain individuals of social groups on property, due to the effect of propertyology, gain form and clarity, they become systematic and organized; thus, one may say that propertyology changes a person's worldview regarding the property in a better way.

Methodological function. Propertyology starts playing

*Disclosure: The publication has been prepared with the support of the "RUDN University Program 5-100" the role of a common methodology for all sociohumanitarian disciplines, studying property.

Diagnostic function. Propertyology "diagnoses" the existing development trends in their regard to the institution of property or ownership rights, including both global and local aspects of the said development.

Forecasting function is contained in the following principle: propertyology shall predict the future trajectories of the property's development, foresee the possible ways of its evolution. In general, an issue of the "future of property" can be called "future-property" (ref. parts II and III).

Integrative function. Propertyology collects, summarizes, and universalizes all the knowledge regarding property but not rising at the same time to the philosophical level of generalization. The main task is the task of the "librarian archivist" - to collect, put together, describe, perform a primary analysis of the existing data. Funded analysis is here possible only with the involvement of philosophical data and methods, which propertyology initially lacks.

Didactic function involves the use of propertyology as an academic discipline in the educational process.

The realization of the aforementioned six functions, in our opinion, allows propertyology to actively pursue the synthesizing function regarding the property and to fully assert itself as a new interdisciplinary field of research.

\section{PROPERTY OF HUMAN BODY AND INTELLECTUAL PROPERTY}

The property problem is one of the key problems of the future post-industrial society. The main thesis may seem a bit tautological, but it goes like this: "Property in the future post-industrial society will remain to be one of the most important social institutions that regulate economic and social relations among people". The end of the property (reminding on F. Fukuyama's concept of "the end of history) is out of the question; property isn't facing communization or transformation into quasi-property, non-property. On the contrary, the role and importance of property in the postindustrial era will increase; new types of property will enter circulation, the legislative framework of all possible "proprietary" relations will be even more deeply developed, 
and, what is equally important, the role of tradition and morality will become even more significant in regulating various aspects of interaction within property and among owners.

Now let us support this thesis. We associate the emergence of the new types of property with the further progress of science and technology, as well as the improvement of legislation, elimination of "legal gaps" in regulating the turnover of certain intellectual or physical objects. First of all, we assume that the subsequent progress of medicine and biology will force the legislators to introduce the concept of "property of the human body", that shall unite in itself such concepts as "property of the human organs" "property of the human embryo (fetus)", "property of the cells, intended for cloning and nurtured objects (clones)", etc. A human body to even greater extent will become an object of legislative and moral regulation and the property rights for it will become more and more tangled and specific. Even now there are plenty of moral and legal problems in regulating the "property of a human body". For example, these are the problems of surrogacy, in vitro fertilization, abortions (and the following disposal of the embryo), etc. The legal status of the human embryo is still uncertain and, as pointed out by I.A. Ivanov, "the lawyers face a complicated task to determine the legal position of the human embryo on the basis of modern scientific achievements" [2]. No less urgent is the problem of property of the body parts, manifesting itself in transplantology. V.I. Kolotayeva states that in order to solve the issues with the organs transplantation, it is necessary "to solve the organizational and worldview problems to consolidate in the public consciousness the idea of the usefulness of transplantation for the whole society" [3].

Some authors derive from the existence of "property of the human body" (albeit not formally recognized by the legal science) the existence of such exotic types of property as "erotic property", "sexual property", and "marital property". The concept of "erotic property", e.g., is used by R. Collins. He says literally the following: "If the property is rather a social attitude than a thing in itself, then it makes sense to review love and sex as forms of property. The key question of property is the right of possession, right to take possession and the society's desire to support these rights. The core of marriage is property in this sense" [4].

R. Collins also views "sexual property" and "marital property" as forms of "erotic property". In his thoughts, "marriage in our society is a contract between two people to acquire exclusive rights to sexual possession. Implicitly speaking, they arbitrarily exchange their bodies as sexual property with each other" [5].

The other type of property, which meaning (as both economic and legal object) will continue increasing is intellectual property. It has long overgrown the framework of the legal institution of copyright and patent rights and demands an urgent revision of all traditional legal, economic and philosophical ideas about itself. The immediate tasks include the introduction of the scientific intellectual property into legal circulation (as property of "scientific discoveries"
- at least in the field of natural sciences1), the recognition of "qualification" and "education" as kinds of intellectual property, the assignment to a person, professionally engaged in intellectual activities, the right to preferential appropriation of the created ideas and concepts (both inside and outside the framework of the legal institution of intellectual property).

In particular, the copyright protection on the Internet, and, in general, everything, linked to the global network, creates considerable difficulties. A well-known researcher S. Babkin, for example, is pessimistic towards the potential of the Internet in solving this problem: "The Internet is such an infrastructure of mass culture, which at the tech level makes it much more effective to sell large volumes of information and not the specific products. The Internet is by its nature out of the scope of copyright laws. Theoretically, it is possible to apply the existing basic and modified copyright laws to the Internet. Yet, in fact, this will not lead to any effect. ... The current architecture of the Internet is extremely hostile to effective copyright regulation" [6].

\section{NETWORK PROPERTY}

Our next thesis: future-property as the property of the future will have a network feature - in the spirit of "network society" theory, developed by the Spanish economist Manuel Castells [6]. According to Castells, "network society" is a society, based on such a form distribution of knowledge and substance, where the means of producing the new resources are established by "crossing the segments of autonomous systems of goals" [7], i.e., network society is organized on the principle of a decentralized network, where each cell (or unit) functions as if by itself, but, forming a common structure with other cells (or units), is able to give the network the functions of an integral whole.

Returning to the problem with the Internet, it should be pointed out, that the Internet is a classic example of such a network. As such, this network doesn't have an owner, and any given element may function both autonomously and interacting with the other elements. The network structure is a self-governing and self-regulating structure without a control center, able to develop and reproduce limitlessly, without losing its qualitative properties. The premise of the existence of "network property" in the present and in the future could be deduced from our previous argumentation paragraph. At times it is almost impossible to specify people, responsible for certain rights - rather, there is a multicellular network of owners, connected to each other via a certain system of mutual obligation - in the context of dominating corporate ("group" in a broad sense) property, showing a huge variety of forms and blurred accountability: "Who is the owner? Who is the manufacturer? Who is the master? Who is the servant? These concepts are becoming increasingly blurred in the context of a system of production described by the ever-changing configuration, networking, creation of networks, the involvement of external sources, the use of subcontractors" [8].

Let us recall, that there was a state registration of the scientific discoveries in the USSR. 
The basis of "network property" in the post-industrial era is the "network enterprise", which, according to Castells, "forms the material basis of a culture in the information/global economy: it turns signals into goods by processing knowledge" [9].

Of course, we are unlikely to label every kind of futureproperty as "network property". First of all, we are talking about the tendency, inherent to a large part of the property of the future - intellectual and material. We may assume that the first type of property (intellectual one) is more subject to such transformation and it can play the role of a kind of "icebreaker" on the way to the "network economy" and "network society.

\section{CREATIVE Class AND PROPERTY}

The current theories of the "creative class" also demand attention to the property in its futuristic aspect. The attitude towards the intellectuals as a potential part of the "creative class" differs drastically among the researchers: some are very optimistic and believe that the intellectuals will become the part of the "creative class", that will determine the trends of the global transformations of the post-industrial era, while others, vice versa, believe, that the owners and managers of the material resources will continue to discriminate and exploit the owners of the intellectual property. In this case, the intellectuals as the owners of the intellectual property face the fate of becoming part of the "precariat" - the new lowest class of the modern era.

In particular, Zh. Toschenko defines the class this way:

"Precariat - is a fundamentally new formation, designating the presence of a social class, representing not only the alienation from the products of labor, but from the major social groups, experiencing particularly sophisticated forms of their labor, knowledge, skills, and, ultimately, life exploitation. The precariat includes those constantly (!) engaged in temporary, occasional work, involved in gray or "illegitimate" workforce market, resulting in the reduction of social rights and impaired social status" [10].

Richard Florida expresses the opposite point of view. He claims, that the intellectual labor (especially the creative one) transforms the intellectuals into one of the strata of the "creative class", which should certainly be at the top of the social ladder:

"The main feature of the creative class is that its representatives are engaged in the creation of the significantly new forms. ... The super creative core of the new class includes scientists and engineers, university professors, poets and writers, artists and actors, designers and architects, as well as the intellectual elites of the modern society: publicists, editors, major cultural figures, think tanks experts, observers, and everyone, whose views form public opinion. Whoever they are by the profession - programmers, engineers, architects or film directors - the creative process absorbs them entirely. ... Those, belonging to the core of the creative class, are engaged in similar activities on a regular basis - that's what they are paid for" [11].
The creative class, according to R. Florida, has several key values that support it as a leading force in the postindustrial era: 1. the desire for a self-identity and selfassertion; 2. meritocracy, i.e. the high evaluation of personal abilities; 3. diversity, inclusivity, mobility [12].

\section{CONCLUSION}

So, what conclusions do we draw at the end of our discussions?

Propertyology is a global science on property, revealing the interdisciplinary and transdisciplinary discourses of the institution, generalizing its social practices and constructing on the basis a universal social theory of property.

Future-property as the property of the future is experiencing the following trends in its transformation: the increasing importance of the new types of property, in particular, intellectual property and property of human body; the increase of intellectual component in the future-property; the complexity of the structure of property, its acceptance of the network status.

The creative class as a part of the class of the intellectuals is able to activate the new processes in the transformation of property, including the creation of the new types of identity.

\section{REFERENCES}

[1] A. Orekhov, M. Skachko, Philosophy of Property as the First Premise of Propertyology, RUDN Press (Philosophy), Moscow, vol.1, p.163, 2015.

[2] Ivanova, Criminal-Legal Defense of a Man in the Context of Realization of Reproductive Rights of Its Parents. MGU Press (Series 11 Law) vol. 5, p.134, 2014.

[3] V. Kolotaeva, The Problem of "Presumption of Agreement" on Alienation of Organs and Tissues of a Man after his Death in Law of Russian Federation. MGU Press (Series 11 Law). vol.1, p.108, 2015.

[4] P. Berger, B. Berger, R. Collins, Person-Oriented Sociology, Moscow, Akademicheskii Proekt, 2004, p.532.

[5] P. Berger, B. Berger, R. Collins, Person-Oriented Sociology, Mocow, Akademicheskii Proekt, 2004, p.532.

[6] S. Babkin, Intellectual Property in Internet, Moscow. CentrUrInfoR. 2006. pp.350-355.

[7] M. Casttell, Power of Originality. "Novaja postindustrial'naja volna na Zapade”. Moskwa. VSE. 1999. P.174.

[8] M. Casttells, Power of Originality. "Novaja postindustrial'naja volna na Zapade". Moskwa. VSE. 1999. P.502.

[9] M. Casttells, Power of Originality. "Novaja postindustrial'naja volna na Zapade". Moskwa. VSE. 1999, p.502

[10] Z. Toscshenko, Precariat is a new class, Sotsis. vol. 6, p.3, 2015.

[11] R. Florida, A Creative Class. Moskwa. Klassika-XXI. 2011, p.86.

[12] R. Florida, A Creative Class. Moskwa. Klassika-XXI. 2011, pp.9597. 